\title{
Protein Kinase C Inhibitor IDE196
}

National Cancer Institute

\section{Source}

National Cancer Institute. Protein Kinase C Inhibitor IDE196. NCI Thesaurus. Code

C124796.

An orally available protein kinase C (PKC) inhibitor with potential immunosuppressive and antineoplastic activities. Upon oral administration, protein kinase C inhibitor IDE196 binds to and inhibits PKC, which prevents the activation of PKC-mediated signaling pathways. This may lead to the induction of cell cycle arrest and apoptosis in susceptible tumor cells. PKC, a serine/threonine protein kinase overexpressed in certain types of cancer cells, is involved in tumor cell differentiation, proliferation, invasion and survival. 